\title{
THE FILTRATION RATE, EFFECTIVE RENAL BLOOD FLOW, TUBULAR EXCRETORY MASS AND PHENOL RED CLEARANCE IN NORMAL PREGNANCY ${ }^{1}$
}

\author{
By CATHERINE A. WELSH, IRWIN WELlEN, AND HOWARD C. TAYLOR, JR. \\ WITH THE TECHNICAL ASSISTANCE OF ANNA ROSENTHAL \\ (From the Department of Obstetrics and Gynecology, New York University College of Medi- \\ cine and the Obstetrical and Gynecological Service of the Third (New York \\ University) Surgical Division of Bellevue Hospital, New York City)
}

(Received for publication August 12, 1941)

Alterations in kidney physiology have long been sought to explain certain phenomena of normal pregnancy. Most suggestive of a renal disturbance was the well known tendency of pregnant women to retain salt and water, clinical evidence of which is found in the edema of late pregnancy and in the diuresis of the first few days postpartum. There was also the apparent readiness with which pregnant women developed specific toxemia with its proteinuria. It had indeed been suggested that certain types of toxemia were caused by the alleged strain of pregnancy imposed on the "low reserve" kidney (1).

Additional interest has been given this subject by recent observations that the steroid hormones of the testis and the ovary cause an increased retention of salt and water $(2,3,4,5)$ and when injected into rats and mice lead to a considerable increase in the size of the kidney $(6,7,8)$. Two of these substances, estrogen and progesterone, are produced by the placenta and are present in great concentration in the body fluids of all pregnant women. Good reasons therefore exist for considering the possibility of change in kidney physiology, although no consistent abnormality in renal function has yet been demonstrated in normal pregnancy $(9,10,11)$.

The present report concerns the measurements of glomerular filtration, effective renal blood flow and the total functioning tubular tissue in normal pregnant women. Tests were carried out during pregnancy and were repeated after delivery, so that the effects of delivery on the kidney function of a single individual can be studied.

The rate of filtration at the glomerulus is determined by the inulin clearance, the rate of effective renal blood flow by the diodrast clearance, and the

1 This study was made with the aid of a grant from the Commonwealth Fund. maximum tubular excretory function or tubular excretory mass by diodrast $T_{m}$. The physiological basis for these measurements has been reviewed by Smith and his associates $(12,13,14,15)$. Smith has also recently discussed the functional significance and limitations of renal clearances (16).

\section{MATERIAL}

For the tests patients were selected from the prenatal clinic or the ward. Fifteen women were studied in the last lunar month, three in the ninth month, and three in early pregnancy. Nine of these twenty-one were again tested after delivery. None had hypertension, proteinuria, edema, or a history of kidney disease, hypertension or specific toxemia of pregnancy.

\section{METHOD}

The patient was given a liter of water to drink the evening before the test. The next morning between $7: 30$ and 8:30 she was given another liter. No breakfast was allowed.

Inulin, phenol red and diodrast were given by continuous intravenous infusion at a controlled rate. When this work was begun in May, 1938, physiological saline was used in the infusion fluid. At the same time, tests were started on patients with specific toxemia of pregnancy in whom it was soon found that an adequate urine flow could not be obtained by this method. A two per cent solution of sodium sulphate (anhydrous) in saline was tried next, and later an eight per cent solution of sorbitol or mannitol in distilled water was used.2 From July, 1939 to the present time eight per cent mannitol in distilled water has been employed routinely. With this infusion fluid, the urine flows have ranged from two to ten cc. per minute, usually being about five cc. per minute. The error in clearance values resulting from pos-

${ }^{2} \mathrm{We}$ are indebted to the Winthrop Chemical Company for the diodrast and to the Abbott Laboratories for the mannitol used in this investigation. The inulin used was prepared by the U. S. Standard Products Company, the phenol red by Messrs. Hynson, Westcott and Dunning, and the Sterisol saline and distilled water by Schering and Glatz, Inc. 
sible incomplete emptying of the bladder was minimized by maintaining a high urine flow. Any test in which this was below two cc. per minute was discarded.

Urine specimens were collected by a six-holed rubber catheter left in the bladder throughout the test. At the end of each urine collection period the bladder was washed out with physiological saline followed immediately by insufflation with air. Care in this step is particularly necessary in studying patients in late pregnancy, because the fetal head makes impossible the suprapubic pressure usually employed to insure complete emptying.

Two or three venous blood samples were taken during the clearance periods, and three during the diodrast $T_{m}$ periods. Plasma levels of diodrast, phenol red and inulin were interpolated to the midpoint of each urine collection period.

Blood pressures, pulse rates, and mouth temperatures were taken at frequent intervals throughout the test. Hematocrits were determined on the sample of blood taken just before the infusion was begun. The first urine sample was examined routinely for protein and formed elements.

Iodine was analyzed by the Kendall method (17). Inulin was analyzed by the method of Folin $(18,19)$ in the earlier experiments and by that of Alving, Rubin and Miller (20) in the more recent ones. Certain modifications of these methods were introduced according to published directions by Smith et al. and Goldring et al. (14, 21).

\section{RESULTS}

Inulin and phenol red clearances were done on twenty normal pregnant women, with diodrast clearance in eleven and diodrast $T_{m}$ in eight. After delivery inulin and phenol red clearances were done on ten women, with diodrast clearance and diodrast $T_{m}$ in six.

The values for the three clearances, the diodrast $T_{m}$ and the significant ratios are given in Table I. Each clearance figure is the average of three or more urine collection periods, each diodrast $T_{m}$ the average of five. The inulin clearances average $124 \mathrm{cc}$. per minute antepartum and $116 \mathrm{cc}$. per minute postpartum; the phenol red clearances average $371 \mathrm{cc}$. per minute antepartum and $362 \mathrm{cc}$. per minute postpartum; diodrast clearances average $631 \mathrm{cc}$. per minute antepartum and $525 \mathrm{cc}$. per minute postpartum. The effective renal blood flow appears in the table only in the cases in which diodrast clearances were done. Before delivery the average value is $970 \mathrm{cc}$. per minute and after delivery it is $858 \mathrm{cc}$. per minute.

The filtration fraction, or inulin/diodrast clearance ratio, which measures the proportion of the effective plasma flow filtered at the glomerulus, is nearly identical antepartum and postpartum. The inulin/phenol red clearance ratio is used to indicate changes in filtration fraction in those instances where diodrast clearances were not done, on the assumption that any change in inulin/phenol red clearance ratio reflects a similar change in filtration fraction of the same functional significance, if not of identical degree. The figures for this ratio antepartum and postpartum are likewise nearly identical. The phenol red/diodrast clearance ratio, although varying widely in different individuals, shows no consistent change between antepartum and postpartum observations in the same individuals.

The diodrast $T_{m}$ averages $45.6 \mathrm{mgm}$. of iodine per minute antepartum and $46.6 \mathrm{mgm}$. of iodine per minute in postpartum observations. In the last three columns the effective renal blood flow, diodrast clearance, and inulin clearance have been related to the diodrast $T_{m}$. This is a convenient way in which to compare figures in different individuals because kidney function as measured by the respective clearances is related to standard amounts of renal tissue and variations due to kidney size are thereby eliminated.

Review of the data in Table I shows that no significant changes occur in inulin clearance, phenol red clearance, diodrast clearance or diodrast $T_{m}$ in pregnancy when renal function is compared to the postpartum observations as a standard of reference.

Comparison of the average figures from the smaller groups made up only from those individuals on whom both antepartum and postpartum observations were made (Table II) again shows no significant differences. Diodrast clearance and diodrast $T_{m}$ were determined in only three subjects both antepartum and postpartum. While this is a small group to average, the figures again indicate no change in renal function.

Comparison of our results in pregnancy and the puerperium with those in normal non-pregnant women, as observed by Goldring, Chasis, Ranges and Smith (21), and normal non-pregnant and pregnant women, as observed by Chesley and Chesley $(10,11)$ appears in Table III. Our clearances, ratios and clearances per unit $T_{m}$ in pregnancy are almost identical with those in nonpregnant women, as reported by Goldring et al. 
RENAL FUNCTION IN NORMAL PREGNANCY

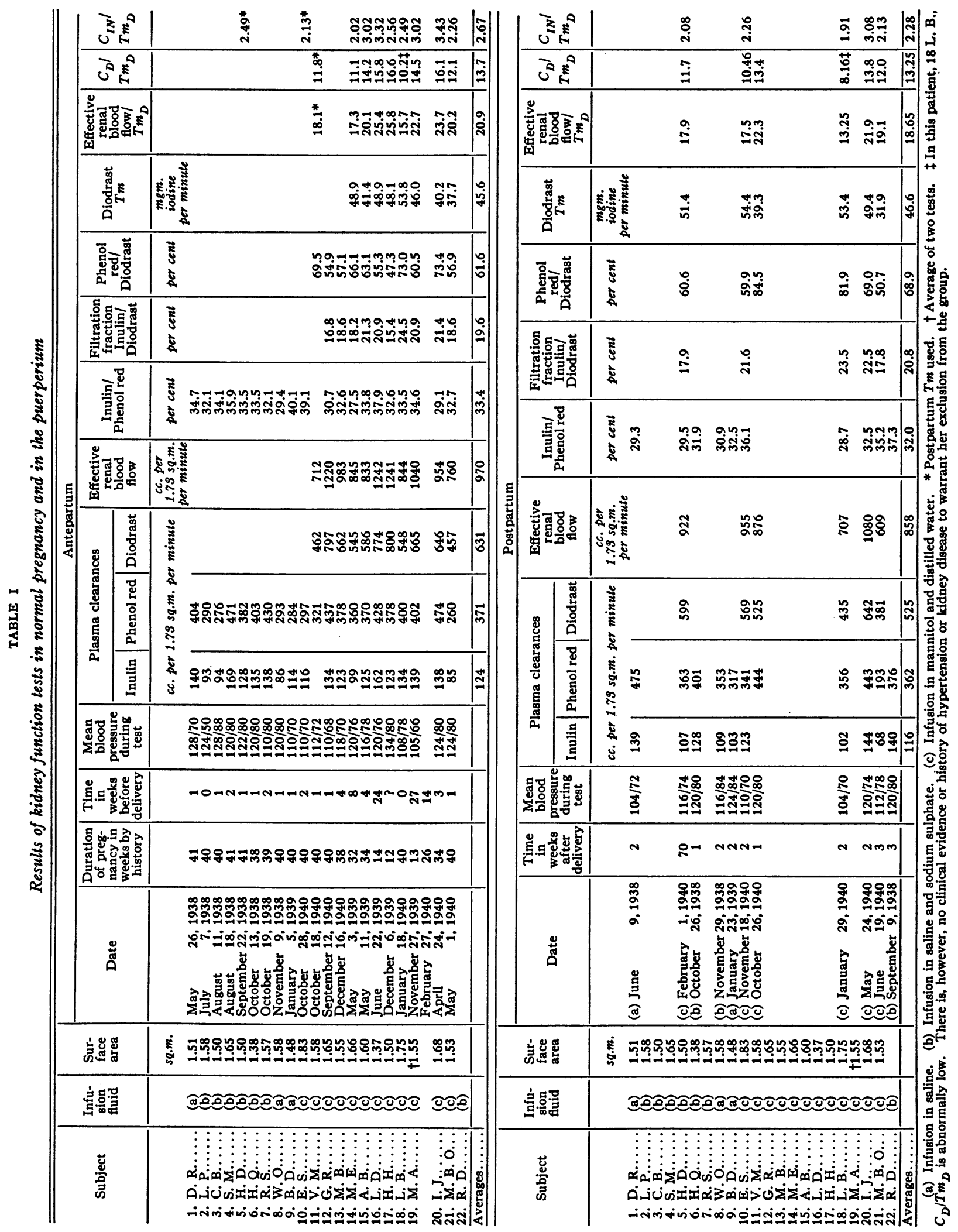


TABLE II

Averages of antepartum and postpartum observations in same patients

\begin{tabular}{|c|c|c|c|c|c|c|c|c|c|c|c|}
\hline \multirow{2}{*}{ Number and type of case } & \multicolumn{3}{|c|}{ Plasma clearances } & \multirow{2}{*}{$\begin{array}{l}\text { Effec- } \\
\text { tive } \\
\text { renal } \\
\text { blood } \\
\text { flow }\end{array}$} & \multirow{2}{*}{$\begin{array}{c}\text { Inulin/ } \\
\text { Phenol } \\
\text { red }\end{array}$} & \multirow{2}{*}{$\underset{\text { Diodrast }}{\text { Inulin/ }}$} & \multirow{2}{*}{$\begin{array}{l}\text { Phenol } \\
\text { red/ } \\
\text { Diodrast }\end{array}$} & \multirow{2}{*}{$\underset{T_{m}}{\text { Diodrast }}$} & \multirow{2}{*}{$\begin{array}{l}\text { Effec- } \\
\text { tive } \\
\text { renal } \\
\text { blood } \\
\text { flow/ } \\
T_{m_{D}}\end{array}$} & \multirow{2}{*}{$C_{D} / T_{m D}$} & \multirow{2}{*}{$\begin{array}{l}C_{I N /} \\
T_{m_{D}}\end{array}$} \\
\hline & Inulin & $\begin{array}{l}\text { Phenol } \\
\text { red }\end{array}$ & Diodrast & & & & & & & & \\
\hline 9 antepartum & $\begin{array}{c}c c . \text { per } 1 \\
120\end{array}$ & $\begin{array}{l}\text { sq. m. } \\
355\end{array}$ & or minute & $\begin{array}{l}c c . \text { per } \\
1.73 \text { sq. } \\
\text { m. per } \\
\text { minute }\end{array}$ & $\begin{array}{c}\text { per cent } \\
33.8\end{array}$ & per cent & per cent & $\begin{array}{l}\text { mgm. } \\
\text { iodine } \\
\text { per } \\
\text { minute }\end{array}$ & & & \\
\hline 9 postpartum & 114 & 360 & & & 31.7 & & & & & & \\
\hline 3 antepartum & 119 & 378 & 550 & 852 & 31.5 & 21.6 & 68.7 & 43.9 & 19.4 & 12.5 & 2.71 \\
\hline 3 postpartum & 105 & 331 & 486 & 800 & 31.7 & 21.6 & 68.1 & 44.9 & 17.8 & 10.8 & 2.34 \\
\hline
\end{tabular}

TABLE III

Averages of normal pregnant women compared with normal non-pregnant women and normal men

\begin{tabular}{|c|c|c|c|c|c|c|c|c|c|c|c|}
\hline \multirow{2}{*}{ Number and type of case } & \multicolumn{3}{|c|}{ Plasma clearances } & \multirow{2}{*}{$\begin{array}{c}\text { Effec- } \\
\text { tive } \\
\text { renal } \\
\text { blood } \\
\text { flow }\end{array}$} & \multirow{2}{*}{$\begin{array}{l}\text { Inulin/ } \\
\text { Phenol } \\
\text { red }\end{array}$} & \multirow{2}{*}{ 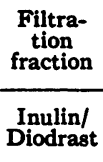 } & \multirow{2}{*}{$\begin{array}{c}\text { Phenol } \\
\text { red/ } \\
\text { Diodrast }\end{array}$} & \multirow{2}{*}{$\underset{T_{m}}{\text { Diodrast }}$} & \multirow{2}{*}{$\begin{array}{c}\text { Effec- } \\
\text { tive } \\
\text { renal } \\
\text { blood } \\
\text { flow/ } \\
T_{m} D\end{array}$} & \multirow{2}{*}{$C_{D} / T_{m_{D}}$} & \multirow{2}{*}{$\begin{array}{l}C_{I N I} \\
T_{m_{D}}\end{array}$} \\
\hline & Inulin & $\begin{array}{c}\text { Phenol } \\
\text { red }\end{array}$ & Diodrast & & & & & & & & \\
\hline $\begin{array}{l}9 \text { normal non- } \\
\text { pregnant women* }\end{array}$ & \multicolumn{3}{|c|}{ cc. per 1.73 sq. $m$. per minute } & $\begin{array}{c}c c . \text { per } \\
1.78 \text { sq. } \\
m_{.} \text {per } \\
\text { minute } \\
996\end{array}$ & per cent & $\begin{array}{c}\text { per cent } \\
19.8\end{array}$ & per cent & $\begin{array}{c}\underset{\text { mgm. }}{\text { modine }} \\
\text { per } \\
\text { minute } \\
46.7\end{array}$ & 21.3 & 12.8 & 2.54 \\
\hline 30 normal men* & & & & & 32.2 & & & & & & \\
\hline $\begin{array}{l}15 \text { normal non- } \\
\text { pregnant women } \dagger\end{array}$ & & & 545 & 844 & & & & & & & \\
\hline $\begin{array}{l}15 \text { normal pregnant } \\
\text { woment }\end{array}$ & & & 591 & 856 & & & & & & & \\
\hline $\begin{array}{l}20 \text { normal pregnant } \\
\text { women }\end{array}$ & 124 & 371 & & & 33.4 & & & & & & \\
\hline $\begin{array}{l}8 \text { normal pregnant } \\
\text { women }\end{array}$ & 126 & 384 & 628 & 970 & 32.9 & 20.1 & 61.2 & 45.6 & 21.3 & 13.7 & 2.77 \\
\hline
\end{tabular}

* Goldring, Chasis, Ranges and Smith.

† Chesley and Chesley.

The diodrast clearances are also essentially the same as those reported by Chesley and Chesley. ${ }^{3}$

Renal function as revealed by these tests is unaltered by normal pregnancy and undergoes no

3 Chesley's infusions contained only glucose and diodrast; infusions used by Goldring, Chasis, Ranges and Smith contained inulin and diodrast in saline; our infusions were made up of inulin, phenol red, diodrast and, in various instances, saline, sodium sulphate or sorbitol or mannitol. The close comparison of diodrast clearance figures found in these three groups seems to rule out Chesley's suggestion (10) that infusions of inulin and phenol red may cause a renal hyperemia. change in the days immediately following delivery. One cannot therefore explain the slight salt and water retention of normal pregnancy on the basis of a decreased filtration rate. There is no evidence of any hormonal effect on kidney function which might accompany the morphological change known to follow the injection of similar substances into small laboratory animals.

\section{CONCLUSION}

The filtration rate (inulin clearance), effective renal blood flow (diodrast clearance), tubular ex- 
cretory mass (diodrast $T_{m}$ ) and phenol red clearances are not altered in pregnancy or in the puerperium of normal women.

\section{BIBLIOGRAPHY}

1. Stander, H. J., and Kuder, K., Low reserve kidney. Am. J. Obst. and Gynec., 1938, 35, 1.

2. Taylor, H. C., Jr., Warner, R. C., and Welsh, C. A., The relationship of the estrogens and other placental hormones to sodium and potassium balance at the end of pregnancy and in the puerperium. Am. J. Obst. and Gynec., 1939, 38, 5, 748.

3. Thorn, G. W., Engel, L. L., and Eisenberg, H., Effect of corticosterone and related compounds on renal excretion of electrolytes. J. Exper. Med., 1938, 68, 161.

4. Thorn, G. W., and Engel, L. L., Effect of sex hormones on renal excretion of electrolytes. J. Exper. Med., 1938, 68, 299.

5. Thorn, G. W., Nelson, K., and Thorn, D. W., Study of mechanism of edema associated with menstruation. Endocrinology, 1938, 22, 155.

6. Ludden, J. B., Krueger, E., and Wright, I. S., Effect of testosterone propionate, estradiol benzoate, and desoxycorticosterone acetate on the kidneys of adult rats. Endocrinology, 1941, 28, 619.

7. Selye, $H$., The effect of testosterone on the kidney. J. Urol., 1939, 42, 637.

8. Selye, H., On the protective action of testosterone against the kidney-damaging effect of sublimate. J. Pharm. and Exper. Therap., 1940, 68, 454.

9. Chesley, L. C., Renal function tests in the differentiation of Bright's disease from so-called specific toxemia of pregnancy. Surg., Gynec. and Obst., 1938, 67, 481.

10. Chesley, L. C., and Chesley, E. R., The diodrast clearance and renal blood flow in normal pregnant and non-pregnant women. Am. J. Physiol., 1939, 127, 731.

11. Chesley, L. C., and Chesley, E. R., Renal blood flow in women with hypertension and renal impairment. J. Clin. Invest., 1940, 19, 475.

12. Chasis, H., Ranges, H. A., Goldring, W., and Smith, H. W., The control of renal blood flow and glomerular filtration rate in normal man. J. Clin. Invest., 1938, 17, 683.

13. Smith, H. W., The Physiology of the Kidney. Oxford University Press, New York, 1937.

14. Smith, H. W., Goldring, W., and Chasis, H., The measurement of the tubular excretory mass, effective blood flow, and filtration rate in the normal kidney. J. Clin. Invest., 1938, 17, 263.

15. Smith, H. W., Chasis, H., Goldring, W., and Ranges, H. A., Glomerular dynamics in the normal kidney. J. Clin. Invest., 1940, 19, 751.

16. Smith, H. W., Note on the interpretation of clearance methods in the diseased kidney. J. Clin. Invest., 1941, 20, 631.

17. Kendall, E. C., Determination of iodine in connection with studies in thyroid activity. Third paper. J. Biol. Chem., 1920, 43, 149.

18. Folin, O., Two revised copper methods for blood sugar determinations. J. Biol. Chem., 1929, 82, 83.

19. Samoggi, M., A method for the preparation of blood filtrates for the determination of sugar. J. Biol. Chem., 1930, 86, 655.

20. Alving, A. S., Rubin, J., and Miller, B. F., A direct colorimetric method for the determination of inulin in blood and urine. J. Biol. Chem., 1939, 127, 609.

21. Goldring, W., Chasis, H., Ranges, H. A., and Smith, H. W., Relations of effective renal blood flow and glomerular filtration to tubular excretory mass in normal man. J. Clin. Invest., 1940, 19, 739. 